\begin{tabular}{c} 
Volume and Issues Obtainable at Center for Sustainability Research and Consultancy \\
Journal of Business and Social Review in Emerging Economies \\
ISSN: 2519-089X (E): 2519-0326 \\
Volume 5: No. 1, June 2019 \\
CSRᄃ \\
Journal homepage: www.publishing.globalcsrc.org/jbsee \\
\hline
\end{tabular}

\title{
Authoritarian Nature of the People's Democratic Party on Federal Radio Corporation of Nigeria in the Fourth Republic (1999-2015)
}

\author{
${ }^{1}$ Muktar Bashir \\ ${ }^{1}$ School of International Studies, Universiti Utara Malaysia \\ Department of Political Science, Usmanu Danfodio University, Sokoto, P.M.B 2346. Nigeria, Email adress: \\ muktarbashir20@gmail.com
}

\begin{tabular}{|c|c|}
\hline ARTICLE DETAILS & ABSTRACT \\
\hline History & This article empirically discusses the Authoritarian nature of the ruling \\
\hline Revised format: May 2019 & People's Democratic Party (PDP) on Federal Radio Corporation of \\
\hline Available Online: June 2019 & $\begin{array}{l}\text { Nigeria (FRCN) in Nigeria's Fourth Republic between 1999-2015. It } \\
\text { employed qualitative method as a means of data collection and analysis. }\end{array}$ \\
\hline $\begin{array}{l}\text { Keywords } \\
\text { Authoritarian, Elections, FRCN, } \\
\text { Media, Nigeria }\end{array}$ & $\begin{array}{l}\text { The primary data was generated via in-depth Interviews with relevant } \\
\text { stakeholders who were purposively selected. Secondary data was also } \\
\text { utilized to compliment the interviews. The article is written within the } \\
\text { purview of the Authoritarian theory of communication and it was found }\end{array}$ \\
\hline $\begin{array}{l}\text { JEL Classification: } \\
D 72, L 82, L 89\end{array}$ & $\begin{array}{l}\text { that FRCN between the period under study has been dominated, controlled } \\
\text { and dictated by the ruling PDP, reporting issues unethically. The outfit } \\
\text { was mostly dancing to the tune of the party in power (PDP). It is } \\
\text { recommended that FRCN should not be directly controlled by the } \\
\text { government or party in power. Also, a law should be put in place to make } \\
\text { it discharge its responsibility of communicating vital, truthful and } \\
\text { objective information fairly for the people to be equipped with factual } \\
\text { information capable of bringing the needed informed decision particularly } \\
\text { during elections. }\end{array}$ \\
\hline
\end{tabular}

(C) 2019 The authors, under a Creative Commons Attribution-

NonCommercial 4.0

Corresponding author's email address: muktarbashir20@gmail.com

Recommended citation: Bashir, M., (2019). Authoritarian Nature of the Peoples Democratic Party on Federal Radio Corporation of Nigeria in the Fourth Republic (1999-2015). Journal of Business and Social Review in Emerging Economies, 5 (1), 99-106

DOI: $10.26710 / \mathrm{jbsee} . \mathrm{v} 5 \mathrm{i} 1.553$

\section{Introduction}

No society can develop without effective communication and information sharing between and among different interest groups (Lal, 2017). In modern time, the media is saddled with the responsibility of communicating vital and truthful information to the populace to enable them make informed choices especially during elections. An informed citizenry is an asset to any competitive democracy like that of Nigeria. Therefore, the centrality of the media in transforming a democratic society to the upper level has been attested and re-attested by different scholars (Chen, Ping, \& Chen, 2015; Ellison \& Hardey, 2014; Kent, 2013; Mancini, 2013; Santas \& Ogoshi, 2016). The Nigerian democratic journey in the current republic came into play after more than a decade of a prolonged Military rule which was authoritarian in nature. The country transited to civil rule beginning from 1999 to date. A retired general (Olusegun Obasanjo) emerged victorious after the 1998-1999 general elections as the president of the 
country under the platform of Peoples Democratic Party (PDP). The party dominated the political landscape of the country till 2015 when the party lost to the opposition All Progressive Congress (APC).

There was an agreed consensus among scholars that the 1999 transitional programme that was originated, promoted and executed by the Military and their allies was a shallow one resulting to what Ihonvbere (1999:6) and others termed as "transition without change". This can be observed by looking closely at the "visibility of the retired generals with their financial muscles in the polity as well as an authoritarian hangover resulting from the long years of military kleptocracy (Olukoyun, 2004:70). After the 1999 general elections, the military and the new President Obasanjo militarized the institutions of governance including the media such as FRCN. The media was directly force to serve the government interest. Instead, it should be allowed to perform its normative function of educating, informing and entertaining the public with truthful information fairly that is capable of informing the general public in making informed decisions particularly during elections. Scholars have written vast of literature dealing with the activities of the media during elections generally. However, there is scanty attention on the authoritarian nature of the ruling party (PDP) on the largest radio station (FRCN) in the electoral politics of Nigeria with special focus to the current fourth republic between 1999-2015. It is on this note; the article tends to fill the huge gap created in the literature which justifies the direction of the study.

\section{Overview of Federal Radio Corporation of Nigeria (FRCN)}

The Federal Radio Corporation of Nigeria (FRCN) came into being in 1933 by the British colonial government. It started as Radio Diffusion Service (RDS), which allowed the public to hear news and programmes emanating from British Broadcasting Corporation's radio service at a designated location through loudspeakers (Atoyebi, 2001).

The RDS was transformed to Nigerian Broadcasting Service (NBS) with stations in Kano, Kaduna, Lagos, Ibadan and Enugu. By April 1st, 1957, an act of parliament reorganized the service into the Nigerian Broadcasting Corporation (NBC) whose mission was to provide independent and impartial services to the people of what is today referred to as Nigeria. Other stations of the NBC came into limelight in 1962 which included; stations from Onitsha, Port Harcourt and Calabar in the Eastern part of Nigeria; Katsina, Maiduguri, Sokoto, Zaria, Ilorin and Jos in the North and Ijebu-Ode, Abeukuta and Warri in the West. All these stations were serving as subsidiary to the regional station. The local or subsidiary stations broadcast programmes of local concern during the part of the day, and then connect to their regional stations for regional programmes. The national programmes were transmitted from two shortwave transmitters and one medium wave transmitter located in Segunle close to Lagos.

All the three regions (North, West \& East) established their regional stations (Olukotun, 2002). The Western Region started, when Awolowo (the western regional leader) was denied access to the NBC to respond to allegation made by the colonial government of Sir. Macpherson in 1954. They established their TV and radio station collectively referred to as Western Nigerian Broadcasting Service (WNBS) in May, 1960. However, by October 1st, 1960 and 1962, the Eastern and Northern region came up with their stations respectively (Uche, 1989), as Eastern Nigeria Broadcasting Service and Broadcasting Company of Northern Nigeria (BCNN). Moreover, NBC was used by the Federal Government to actualize its mission, the same thing applies to the regional stations. They were out to serve only the regional interest. By April 1st, 1978, the NBC was directed to handover all its subsidiary stations to the Federal Government. What was left for NBC was its original stations in Lagos, Ibadan and Enugu, which were merged with BCNN to constitute the Federal Radio Corporation of Nigeria (FRCN) (Amadi \& Atoyebi, 2001).

\section{Methodology}

The article is embedded within the interpretivist philosophical approach of research. It involves qualitative method of data collection. The data was generated through in-depth interviews with informants who were purposively selected to answer the research question. The people interviewed falls within the following categories; media practitioners; academicians; party members and members of non-governmental organization that monitored different elections in the country. These informants were given codes that represent them in the analysis. The table below summarize the information of the informants and the dates they were interviewed. 
Table 1.1 Information of informants, categories and the date interviewed

\begin{tabular}{lclc}
\hline Categories & & Informants Code & Date interviewed \\
\hline & & & \\
Media Practitioners & A & A1 & 20th May, 2017 \\
& & A2 & 4th Sept, 2017 \\
NGO & B & B1 & 17th July, 2017 \\
& & B2 & 8th Aug, 2017 \\
Pol. Party Members & C & C1 & 5th June, 2017 \\
& & C2 & 5th June, 2017 \\
Academicians & D & D1 & 7th July, 2017 \\
& & D2 & 5th Aug, 2017 \\
& & D3 & 5th Aug, 2017 \\
\hline
\end{tabular}

\section{Justification for the selection of the Informants}

They were selected considering their position and the vital knowledge they possess in relation to the subject matter (Seawnght \& Gerring, 2008). However, qualitative method of data analysis was used to present and analysed the data based on the objective of the paper. The analysis was used through Nvivo 11 software. The software is a qualitative one that assist researchers to systematically arrange and manage date. Its usage is necessary as captured by Richards (2015); Silver and Lewins, (2014) when they stated that it is fair to say that the researcher who does not use software beyond a word processor will be hampered in comparison with those who do. This showcases the fact that using computer aided software in qualitative study adds value to the researcher as he/she gain more skills compared to others.

\section{Authoritarian theory of Communication}

The theory is one of the four normative theories of communication that was recognized by Siebert, Petterson and Shramm (1956). It originated in the 16th Century England, when monarchs used this approach to dictate the affairs of their locality. Kunczick, (1988:3) provides that "recognition of the truth was entrusted in the hands of the few elites able to exercise power in a top-down approach". Therefore, whether the ownership of the media is publicly or privately handled, the authoritarian media must in this respect uphold what the authorities want at all times (McDermott, Fowler, \& Smirnov, 2008). For them, the authorities exist to serve the interest of all and as such cannot be criticized under any circumstances (Barker-Plummer, 1995). The media outfits are under the absolute control of the leaders and there is no freedom of the press, no matter the democratic system in place. Censorship is always resorted to protect and boost government image. The people under this theory cannot ask questions, nor can they question the activities of the government, all that is required from them is complete obedience to the government. The theory has been criticized as antithetical to not only electoral process but democracy as a whole (Stevens, Bishin, \& Barr, 2006). However, despites the criticisms, it is still relevant in explaining the authoritarian nature of the ruling PDP on FRCN between the period under study. The party dominated the political scene of the country from 1999 to 2015. Therefore, during this period, PDP dominated all the machineries of governance including the media to dance to its tune against the larger interest. This was not unconnected with the fact that, the media outlet (FRCN) was directly under government control, its finance and employees are all product of the government. Therefore, they must serve the interest of the government or party in power or face charges where and when necessary as would be seen in the next section of the paper.

\section{Result and Discussion of findings}

The figure below showcases the categories of informants that talked on the Authoritarian nature of the ruling party (PDP) on FRCN between the period under study. 


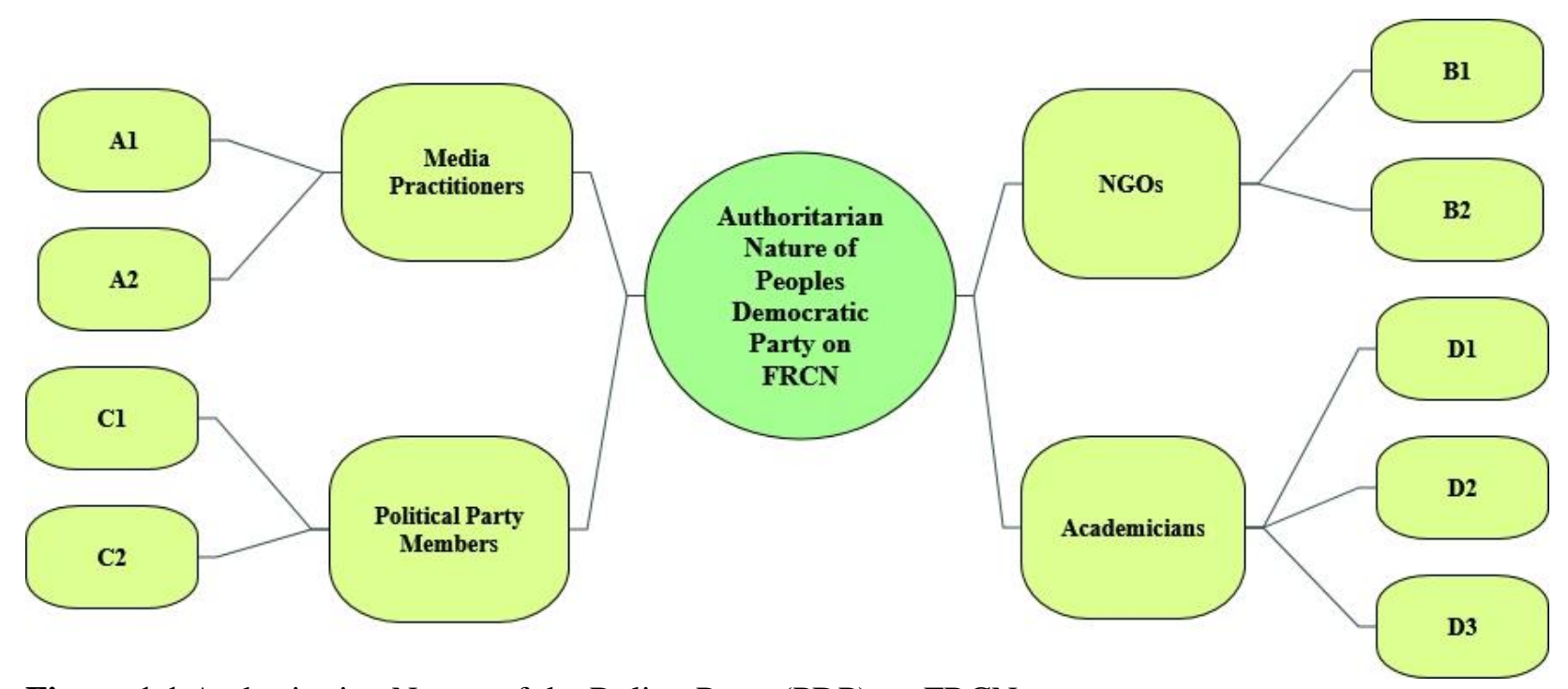

Figure 1.1 Authoritarian Nature of the Ruling Party (PDP) on FRCN Source: Nvivo 11

Democracy is not only about election, it is a work in progress, it does not start and end with elections. Rather, it entails citizens' collective participation in debate concerning their destiny. In addition, citizens must have access to adequate information about the political parties, manifestoes, prospective candidates willing to contest elections as well as information about the electoral processes generally for the people to make informed decisions particularly during elections. Federal Radio Corporation of Nigeria (FRCN) being the dominant radio station in the country (Kur \& Endwell, 2015) is saddled with the responsibility of communicating vital and truthful information for the Nigerian people to actualize the democratic purpose without fair or favour. However, such normative role of the outfit has been compromised by vested interest to the detriment of the larger interests in the polity. An informant disclosed that "FRCN is a government owned media house, so you should understand that there are limitations. The attention of FRCN will basically be on the ruling party against that of the opposition parties" (Interview with B1 on the 17th July, 2017). Lending credence to the above is the fact FRCN and other state-owned radio stations failed to provide equal access and fair coverage to the various competing parties during the 1999 and 2003 general elections (European Union Election Observer Mission EU EOM, 2003). The report further narrates that there was strong bias in the coverage of FRCN to the advantage of the ruling PDP at the federal and other states in the country. However, the bias nature was not unconnected to the following; financial instability of the media, low purchasing power of the population, illiteracy, media reliance on sponsorship for survival, a media culture of deference to the party in power, problems of professional development and the weakness of both government-and self-regulation" (European Union Election Observer Mission, 2003). The media were unable to overcome these challenges and provide adequate coverage of the general elections.

FRCN have the obligation of providing impartial and unbiased information to the electorate, because they are owned publicly as well as their ability to cover widely than any of its kind to relate and reach larger number of people in the country. For example, the outcome of the 2003 election was characterized by all sorts of irregularities and minimum standards of democratic elections were not met. The elections at different levels of governance was challenged in the court of law against the ruling party (EU EOM, 2003).

Moreover, the activities of FRCN during the coverage of 2007 general election was not different from that of the 2003 exercise. An informant added that the scenario of the 2007 election coverage by FRCN have been considered as worse than the previous coverage. The period was characterized by over ambitious of PDP leadership to hold onto power by all means (Interview with D3 on 5th August, 2017). It was observed that President Obasanjo of the ruling PDP monopolized all agencies of governance including the media (FRCN) to serve his interest. He was quoted to have said "winning 2007 elections for me and my party (PDP) is a do or die affair" (Bratton, 2008). This attested to the authoritarian nature of the media outfit by the ruling PDP to the detriment of the opposition parties in particular and the general public in general. This was against the provision of the Electoral Act 2006 as amended under section 102 (1) which provides that "a government owned print or electronic medium shall give equal access on daily basis to all registered political parties and candidates' of such parties". Section 103 (2) added that the state apparatus including the media shall not be employed to the advantage or disadvantage of any political party or 
candidate at any election. On the overall, the outcome of the media coverage on one hand and the conduct of the elections on the other hand were characterized by all sorts of irregularities and bias against the opposition parties (Interview with D2 on the 7th July, 2017). The election was considered as the worst ever conducted in the history of election monitoring across the globe (EU EOM, 2007). The outcome of the election was challenged in the court of law at different levels of governance in the country.

The media outfits (FRCN) prior to the 2007 general elections venture into voter education which was minimal and largely urban focused (EU EOM, 2007). Instead the outfit was expected to dwell much of its political coverage in penetrating all the nooks and crannies of the country which could result to massive voter education and participation in the electoral process. The tensed political atmosphere prior to the election prompted serious comments from United State of America (USA) and United Kingdom (UK) government in relation to the activities of the media in particular and general conduct of the elections in general.

In USA, Army Lieutenant General Micheal D. Maples, Director for Defense Intelligence Agency stated before the US congress that the potential for violence in Nigeria 2007 elections remain high as candidates from the predominantly Muslim North and Christian South compete for office. British on its own side express concern over the issue of press freedom in Nigeria citing the killing of a well-known Lagos journalist and detention of several others in Abuja (EU EOM, 2007). These were so much pronounced against those media outfits and practitioners that goes against the ruling PDP in most cases. Although, the monopolistic nature of the ruling party (PDP) on media outlets in the Nigerian politics was not unconnected with the power bestowed on the media in any democratic settings. In view of this, it is argued that:

Most political parties, who are in the habit of using the media for whatever reason, do so with the intention of retaining public support to maintain and advance their political career, because they are aware that most citizens usually gravitate toward the direction of the media position on public issues. The Nigerian journalists should endeavor to provide sufficient and balanced information on the personality profiles of political aspirants so that the public would be conversant with the history of each of the candidates concerned while deciding on the candidates to votes into public office or parliament. The public often rely on the media for information on the ideologies and manifestoes of political parties, as well as on the competence of the candidates contesting for the elections (Oboh, 2016: 76).

The above showcases the pivotal role of the media practitioners as the custodian of the truth and as such they should in no circumstances be allowed to serve a particular interest against that of the majority.

In 2011, EU EOM observes that there were frequent abuse and misuse of public resources including the media in support of the ruling party (PDP) in the country. For example, during the election period, the ruling party at the federal and state levels merged their official assignments with campaign activities. State-owned broadcast stations such as FRCN devoted a greater amount of time and space in supporting the activities of the ruling PDP (Interview with B2 on the 8th August, 2017). The Europen Union Election Observer Mission (2011) in its reports submitted that there was political reportage of campaign advertisements, praising the ruling party (PDP) at the central level and the President Jonathan before and after his visit in different states of the federation, which was allegedly sponsored and financed by the respective public resources in the various states across the country. This is adequately captured by the Authoritarian theory of communication which argues that he who controls political power monopolize other institutions of governance including the media for his own selfish end (Siebert, Peterson \& Schramm, 1956). This is necessary according to the theorists that, state exist for the sake of life and it continues to exist for the sake of good life. Therefore, the leaders or party in power is always acting for the best interest of the majority, which i believe may not necessarily be the case, as personal interest of the party in power or leaders in most cases dominates the decision making process of the government against that of the general public.

This is against the provision of the regulatory body (National Broadcasting Commission), as provided for under section 5.2.19 that "A broadcaster shall avoid adulation and the tendency to glamorize persons or resort to praise singing or denial of access to those of contrary views or political leanings to such persons"(NBC, 2012: 70). Furthermore, in preparation for the 2011 general elections, there was the existence of 187 radio stations, 109 TV stations, 35 cables and 4 satellite broadcast stations cutting across the country which covered and monitored the 2011 general election (NBC, 2011). However, radio still remains the key medium of communication in the country (EU EOM, 2011). The ruling PDP was severally accused of personalizing the state resources under their control at 
different levels of governance such as vehicles and security personnel to the disadvantage of the opposition parties. In addition, some observers reported incidence of restriction for opposition parties on accessing state-owned space and assets. It was added that, during the electioneering campaign of the 2011 general elections and beyond, the line between the ruling party and the state is often blurred. However, this authoritarian nature of the ruling party on all the machineries of governance led to uneven playing field for the opposition parties (EU EOM, 2011), thereby compromising the ethical nature of the media industry and serving against the legal frameworks of election coverage. Moreover, the 2011 political campaign was quite different with the most controversial election campaign of 2007 in the Nigerian politics, as in the former there was high level of respect to freedom of speech with few cases of harassment, intimidation and police questioning.

It was added that, the ruling party dictated the affairs of the radio station and institution of governance outside the purview of the legal frameworks to dance to its direction (Interview with D3 on the 5th August, 2017). The 2015 general elections equally followed suits as the media was monopolized in favor of some political parties against the others. As captured thus:

The 2015 general election was somehow fair, but FRCN was to a lesser extent bias in its participation. This is because during the electioneering campaigns, you noticed that the media house was biased. They favored the ruling PDP in airing the election campaigns. Not only that, it also engaged in propaganda and offensive campaigns against the major opposition party (APC). That was quite unfair to the affected political party (Interview with $\mathrm{C} 1$ on the 5thJune, 2017).

An informant added that...the management staff of FRCN to be specific were employed and promoted by the ruling PDP government prior to the 2015 elections. As such advertorials or commercials of the oppositions were not accepted in the public media outfits such as FRCN, mostly because some of these adverts were against the ideology of the ruling party... (Interview with D2 on the 7th July, 2017). It was observed that "FRCN happens to be the mouthpiece of the then ruling PDP and as such people boycotted or disregard any information that comes from FRCN and listens more often to independent stations" (Interview with A2 on the 4th Sept, 2017). He further substantiated the above statement in preparation to the 2015 general elections that:

I was called upon in a meeting by the Director-General (DG) of FRCN, after I gave directives on a live political programme called 'Hannu da Yawa' where people called and asked questions about the state of the nation to be aired twice. At the end, the DG clearly told me that he was directed by the then Vice-President Namadi Sambo of the then ruling party (PDP) to inform me that he and the government were not happy with me by giving directives to air live program twice for people to ask questions about the state of the nation. Thereafter, the DG made it very clear that from now henceforth, I and my editors are hereby directed not to air out any jingle (s) or adverts for the opposition party (APC). After the meeting, I drew the attention of the DG reminding him on the danger of such unprofessional directives but he was not listening. I clearly told him that, I cannot be part of this. I communicated same to my editors and left them to make choices on what to do and what not to do. In short there was constant interference by the ruling PDP (Interview with A2 on the 4th Sept, 2017).

In addition, the opposition party before the 2015 election (APC) said that Some private radio stations did their best in striking a balance in covering and disseminating activities of the various political parties compared to FRCN which gave more priority to the then ruling party (PDP) especially at the eleventh hour of the election (Interview with C2 on the 5th June, 2017). It was asserted that:

The private radios being independent stations skillfully and tactically reported the election effectively because they cannot openly take side as their main motive is profit making. Therefore, they need patronage from both sides 'courtesy of commercialization' to make money for its survival. They cannot reject adverts or jingles as what obtained under FRCN which supported the ruling party. The stations largely depend on commercials for survival and as such they attend to he who pays. They were fair in that regard to a very large extent (Interview with D1 on the 7th July, 2017).

It was further corroborated that initially, the opposition parties patronized both public and independent radio stations, but it was later realized that the public stations related more with the party in power (PDP). Therefore, the opposition parties had to utilize the services of some private radio stations which gave fair hearing and equal opportunity to all competing parties. In short, "we mostly patronized all independent media organizations that gave 
fair playing ground for the opposition parties to sell their manifestoes and candidates (Interview with $\mathrm{C} 1$ on the 5th June, 2017).

Therefore, the regulatory body (NBC) whose function is to regulate the activities of the media was also in total control by the party in power. This is considering the view of an informant in relation to the coverage of 2015 general elections in the country thus:

Everyone has witnessed in the last 2015 election campaigns how some media outfits metamorphosed into agents of support to the then ruling PDP or the ruling government. In fact, that led the NBC to call for a meeting of the media controllers in respect of the campaign coverage of the elections and warned us (the media practitioners) against the coverage of provocative comments. I stood up and said, I think the regulatory body does not need to call us for this meeting because they are aware of the media houses that are engaged in covering inciting comments unfairly between and among the competing parties. If at all there is the need for the meeting emphasis should be referred to the media houses involved in the unprofessional act but $\mathrm{i}$ believe the present administration of APC will sanitize the profession (Interview with A1 on the 20th May, 2017).

However, the unfair treatment or political coverage of political parties by the broadcast media is undemocratic and unethical. It burdens to the nascent democratic dispensation of the country. Indeed, the media industry rather than being indulgent and partisan, has a lot of obstacles to take care of in the political life of the nation such as massive awareness on political apathy. As noted that unequal access of the broadcast media industry manifested where: "state institutions were widely abused for partisan ends; the incumbent group or party is systematically favored at the expense of the opposition; and the opposition's ability to organize and compete in elections is seriously handicapped" (Fan \& Pedrycz, 2017: 148). This uneven playing ground is further compounded by the power of finance, as the ruling party has more funds than the opposition groups which gave them upper hand to monopolize the media industry especially relating to commercialization. Lievrouw (2011) supported the above when he asserts that the poor and less endowed groups lack the resources and competence to engage in the intensive competition for media attention and space. An informant further disclosed that:

Most people became so much aware that not only FRCN but also other public media stations became political than otherwise expected. They were partisan and unfair to the public, the people became so disappointed in FRCN in particular, leading people to hate and disregard any information coming from FRCN especially relating to politics and election, thereby contributed immensely to the fall of the ruling party (PDP) at the central level of governance in the country (Interview with B2 on the 8th August, 2017).

Although, the media is supposed to give fair or balanced coverage to the competing groups irrespective of their political party affiliations which will no doubt equip the citizens with adequate information that will encourage them to make informed decision in the electoral politics of the country. However, supporting the course of a particular political party (mostly the ruling party) will no doubt affect the democratic system of the country on one hand and on the other hand, the citizens would be disenchanted with the workings and operations of FRCN in particular and the activities of the government in general. This will affect the citizens' participation in bringing the needed stable and educative society.

\section{Conclusions}

The role of the media cannot be downplayed in any democratic settings like that of Nigeria. The media station under investigation (Federal Radio Corporation of Nigeria) between the period under investigation has been observed to be dominated and dictated by the ruling Peoples Democratic Party in the Nigerian Electoral process. This was not unconnected with the ownership control of the radio station (FRCN) by the ruling government (PDP). The party in power dictates the affairs of the media outlet to the detriment of other interest for selfish purpose. This is however antithetical to democratic dispensation. It is also concluded that, the regulatory body of the media station (National Broadcasting Commission) should be independent of the ruling party's control to make it discharge its responsibility fairly between and among the media outlets. This will no doubt equip the populace with adequate information that will lead to informed decision by the people in supporting a particular political party in any electoral contest. Achieving these would transform the democratic system to the upper level.

\section{References}

Amadi, T \& Atoyebi, A. (2001). Radio Nigeria: Yesterday, Today and Tomorrow. Abuja, Nigeria: Northwood 
resources limited.

Atoyebi, A. (2001). The Origin of Radio Nigeria. Abuja, Nigeria: Northwood resources limited.

Barker-Plummer, B. (1995). News as a Political Resource: Media Strategies and Political Identity in the U.S. Women's Movement, 1966-1975. Critical Studies in Mass Communication, (12), 306-324. https://doi.org/10.1080/15295039509366939

Bratton, M. (2008). Vote buying and violence in Nigerian election campaigns. Electoral Studies, 27(4), 621-632. Retrieved from http://www.sciencedirect.com/science/article/pii/S0261379408000589

Chen, H. T., Ping, S., \& Chen, G. (2015). Far from reach but near at hand: The role of social media for crossnational mobilization. Computers in Human Behavior, 53, 443-451. https://doi.org/10.1016/j.chb.2015.05.052

Ellison, N., \& Hardey, M. (2014). Social Media and Local Government: Citizenship, Consumption and Democracy. Local Government Studies, 40(1), 21-40. https://doi.org/10.1080/03003930.2013.799066

European Union Election Observer Mission. (2003). Nigeria Presidential and Gubernatorial Elections 2003. Abuja, Nigeria. Retrieved from http://www.europarl.europa.eu/meetdocs/committees/afet/20030520/Nigeria 2nd Preliminary Statement.pdf

Fan, K., \& Pedrycz, W. (2017). Evolution of public opinions in closed societies influenced by broadcast media. Physica A: Statistical Mechanics and Its Applications, 472, 53-66. https://doi.org/10.1016/j.physa.2017.01.027

Ihonvbere, J. (1999). The 1999 Constitution of Nigeria: The Limitations of undemocratic Constitution-making. Abuja, Nigeria.

Kent, M. L. (2013). Using social media dialogically: Public relations role in reviving democracy. Public Relations Review, 39(4), 337-345. https://doi.org/10.1016/j.pubrev.2013.07.024

Kunczick, M. (1988). Concepts of Journalism: North and Sourth. Friedrich Ebert-Stifling.

Kur, J., \& Endwell, O. (2015). Television Broadcasting and the Democratization Process in Nigeria: The Successful and Unsuccessful Story. Online Journal of Communication And, 5(4), 116-146. Retrieved from http://search.proquest.com/openview/5753bb581cec0656338005ea7d7ceb38/1?pq-origsite=gscholar

Lal, K. (2017). Investigating ICT infrastructure to develop an information society in India. Universal Access in the Information Society, 16(2), 517-528. https://doi.org/10.1007/s10209-016-0472-1

Lievrouw, L. (2011). Alternative and activist media. Media. Edinburgh University Press. https://doi.org/10.1163/156916307X189068

Mancini, P. (2013). Media Fragmentation, Party System, and Democracy. International Journal of Press/Politics, 18(1). https://doi.org/10.1177/1940161212458200

McDermott, R., Fowler, J. H., \& Smirnov, O. (2008). On the Evolutionary Origin of Prospect Theory Preferences. The Journal of Politics, (2), 335. https://doi.org/10.1017/S0022381608080341

Mission, E. U. E. O. (2011). Report on the Nigerian 2011 General Elections.

National Broadcasting Commission. (2012). Nigerian Broadcasting Code. Lagos: Planet Press Ltd.

Oboh, G. E. (2016). Reflecting on the Nigerian Media, Elections, and the African Democracy. SAGE Open, 6(3), 215824401666688. https://doi.org/10.1177/2158244016666886

Olukotun, A. (2002). Authoritarian state, crisis of democratization and the underground media in Nigeria. African Affairs, 101(404), 317-342. https://doi.org/10.1093/afraf/101.404.317

Olukoyun, A. (2004). Media Accountability and Democracy in Nigeria, 1999-2003. African Studies Review, 47(3), 69-90.

Richards, L. (2015). Handling Qualitative Data: A Practical Guide (2nd ed.). SAGE Publication.

Santas, T., \& Ogoshi, J. (2016). An Appraisal of Mass Media Role in Consolidating Democracy in Nigeria. African Research Review, 10(1), 73-86. Retrieved from http://www.ajol.info/index.php/afrrev/article/view/129819

Seawnght, J., \& Gerring, J. (2008). Case selection techniques in case study research: A menu of qualitative and quantitative options. Political Research Quarterly, 61(2). https://doi.org/10.1177/1065912907313077

Siebert, F; Peterson, T \& Schramm, W. (1956). Four Theories of the Press. Urbana III: University of Illinois Press.

Silver, C., \& Lewins, A. (2014). The Nature of Software Support for Research Projects. In Using software in qualitative research : a step-by-step guide (2nd ed., pp. 35-60). Los Angeles: SAGE Publication.

Stevens, D., Bishin, B. G., \& Barr, R. R. (2006). Authoritarian attitudes, democracy, and policy preferences among Latin American elites. American Journal of Political Science, 50(3), 606-620. https://doi.org/10.1111/j.1540-5907.2006.00204.x

Uche, L. U. (1989). Mass Media, People and Politics. Lagos, Nigeria: Malthouse press Ltd. 